\title{
ÉTICA NAS PRÁTICAS DISCURSIVAS: CONTRIBUIÇÕES PARA O ESTÁGIO SUPERVISIONADO DE LÍNGUA INGLESA ${ }^{1}$
}

\author{
Samantha Mancini RAMOS
}

\section{Resumo}

Este artigo foca na necessidade de se introduzir preceitos de ética e de alteridade nos cursos de formação inicial, principalmente no que tange a prática discursiva do estagiário. Para ilustrar esta necessidade, utilizaremos a Análise Crítica do Discurso para desvendar os aspectos sociais, discursivos e textuais de um trecho de relatório de estágio entregue por um futuro professor de Língua Inglesa. Buscamos esclarecer os seguintes questionamentos: Que linguagem os estagiários utilizaram para falar sobre as aulas que observam e sobre os/as professores/as regentes? Que relações têm formadores e discentes buscado estabelecer entre princípios éticos e práticas discursivas? Como a estruturação do estágio propicia ou não a consideração de preceitos éticos e de alteridade?

Palavras-chave: ética; alteridade; práticas discursivas; formação inicial

\begin{abstract}
This article focus on the necessity of introducing ethical issues in pre-service education courses, mostly referring to trainees' discourse. To illustrate this necessity, we will use Critical Discourse Analysis to reveal the social, discursive and textual aspects of a text produced by a pre-service English teacher. We search to clarify the following questions: What language have trainees used to talk about the lesson they observed and about the teachers? What relations have mentors and trainees tried to establish between ethical principles and discursive practice? How does training structure consider (or not) ethical issues?
\end{abstract}

Key-words: ethics; ‘alteridade’; discursive practices; pre-service education

A Universidade não pode ser vista apenas como instância reflexa da sociedade e do mundo do trabalho. Ela deve ser um espaço de cultura e de imaginação criativa, capaz de intervir na sociedade, transformando-a em termos éticos.” (Diretrizes Curriculares Nacionais/ Letras).

\footnotetext{
${ }^{1}$ Este trabalho foi elaborado como parte da disciplina "Pesquisas em ensino-aprendizagem de línguas estrangeiras: repensando práticas discursivas” ministrada pela Professora Doutora Elaine Mateus, do Programa de Pós-graduação em Estudos da Linguagem da Universidade Estadual de Londrina (UEL).
} 
O estágio supervisionado (doravante ES) é um item obrigatório nos cursos de Letras. Segundo a legislação, os discentes devem cumprir 400 horas de atividades de estágio e cabe a cada instituição organizar sua proposta em relação a esta carga horária.

É grande a expectativa em torno do ES por parte dos discentes e dos próprios formadores sendo que muitos atribuem a este período o papel central da formação inicial. Obviamente o ES não é o ponto de início deste processo porque os discentes já trazem consigo um acúmulo de idéias e experiências que precisam ser consideradas. A formação inicial consistiria, então, da exploração das representações ${ }^{2}$ trazidas pelos discentes, da introdução de novas vivências para a criação de outras representações somadas a tentativa de introduzir componentes teóricos que propiciem reflexões sobre a profissão.

Na estrutura tradicional dos ES, os envolvidos e seus papéis podem ser caracterizados como: 1) o professor formador, representante da instituição universitária, muitas vezes ‘confundido' como o portador do conhecimento e como aquele que tem condições de analisar criticamente a qualidade de ensino dos outros participantes; 2) o professor regente, aquele que representa a verdadeira prática pedagógica, aquele que 'gentilmente' aceita a presença do estagiário, aquele que se deixa ser observado e que muitas vezes tem uma participação periférica no ES; e 3) o discente, também conhecido como estagiário, futuro professor ou aluno/mestre, aquele que muitas vezes serve de ponte entre as instâncias educacionais: a universidade e escola, aquele que tem que considerar as propostas de professores regentes sem frustrar as expectativas dos formadores.

Dentre as atribuições comumente exigidas dos estagiários está a elaboração de diários e de relatórios dos estágios. Este artigo se remete a prática discursiva de uma das vinte discentes do $4^{\circ}$. semestre de um curso de Letras de uma instituição de ensino superior do norte do Paraná que efetuaram as atividades previstas no Estágio Supervisionado de Língua Inglesa II. Os estagiários foram instruídos a observarem 15

\footnotetext{
2 Neste estudo o termo "representações" será utilizado de acordo com as idéias de Freire e Lessa (2003), que apontam as representações como formas socialmente construídas de perceber, configurar, negociar, significar, compartilhar e/ou redimensionar fenômenos, mediadas pela linguagem e veiculadas por escolhas lexicais e/ou simbólicas expressivas que dão margem ao reconhecimento de um repertório que identifica o indivíduo e sua relação sócio-histórica com o meio, com o outro e consigo mesmo (p. 174)
} 
horas/aula de língua inglesa no ensino fundamental e médio e produzirem diários ${ }^{3}$ das aulas assistidas nos quais os contextos educacionais, as práticas docentes, os processos de aprendizagem e os materiais didáticos (ou a falta deles) deveriam ser explicitados ${ }^{4}$. Além da observação e da produção dos diários, os discentes também deveriam preparar um relatório crítico de observação ${ }^{5}$ relatando o contexto escolar, levantando e analisando os aspectos mais relevantes observados a partir das leituras dos PCN de Língua Estrangeira e através dos próprios diários produzidos.

Considerando o contexto acima relatado, este artigo tem por objetivo levantar questionamentos éticos sobre as práticas discursivas de estagiários ao produzirem seus relatórios de observação. O intuito é problematizar as ideologias e as relações de poder que afloram destes relatórios (através da análise crítica do discurso) e trazer contribuições para formadores e discentes quanto a questões de ética e de alteridade. As perguntas que norteiam este artigo são: Que linguagem os estagiários utilizaram para falar sobre as aulas e os/as professores/as regentes? Que relações formadores e discentes têm buscado estabelecer entre princípios éticos e práticas discursivas? Como a estruturação do estágio propicia ou não a consideração de preceitos éticos e de alteridade?

\section{Ética e alteridade nos Estágios Supervisionados}

Neste artigo, entende-se que questões éticas e de alteridade devem ser consideradas no momento da estruturação e da execução das propostas para o estágio supervisionado e no momento da produção textual dos discentes. Passemos então a algumas definições sobre estes termos e suas possíveis relações a formação de professores de línguas estrangeiras, começando pela ética:

A Ética existe em todas as sociedades humanas, e, talvez, mesmo entre nossos parentes não-humanos mais próximos. Nós abandonamos o pressuposto de que a Ética é unicamente humana. A Ética pode ser um conjunto de regras, princípios ou maneiras de pensar que guiam, ou chamam a si a autoridade de guiar, as ações de um grupo em particular (moralidade), ou é o estudo sistemático da

\footnotetext{
${ }^{3}$ Vide instruções para elaboração dos diários de observação conforme consta do manual do estagiário da instituição no anexo 1

${ }^{4}$ Vide proposta para o Estágio Supervisionado de Língua Inglesa 2 conforme consta do manual do estágio da instituição no anexo 2

${ }^{5}$ Vide roteiro para produção do relatório crítico de observação no anexo 3
} 
argumentação sobre como nós devemos agir (filosofia moral). Singer P. Ethics. Oxford: OUP, 1994:4-6.

Questões éticas devem permear o trabalho dos formadores de professores de línguas e dos discentes nos cursos de Letras fazendo com que estes tenham em mente os conjuntos de regras, princípios ou maneiras de pensar que guiam suas ações como citado por Singer. O modo de agir, de interagir e produzir seus discursos mediante estas regras, princípios ou maneiras de pensar passariam a ser aspectos cruciais a serem problematizados desde o início da formação deste profissional.

Ao se referir aos códigos de conduta nas pesquisas em Lingüística Aplicada, Celani (2005) afirma que estes têm por objetivo evitar danos e prejuízos para os participantes da pesquisa, para os próprios pesquisadores e para a sociedade, uma vez que "a perda de confiança na pesquisa e nos pesquisadores pode representar danos irreparáveis” (Celani, 2005, p.107). Da mesma forma como na pesquisa, o ES é um momento que prevê interação entre participantes de esferas culturais diferentes que se relacionam na tentativa de criar um elo entre a escola e a universidade. Portanto, assim como nas pesquisas, também o ES deve garantir segurança e preservação da dignidade dos participantes.

Outro termo relevante a ser considerado é a alteridade, a capacidade de se colocar no lugar do outro na relação interpessoal agindo frente ao outro como gostaria de ser tratado. Goldim (1997) cita Descamps (1991) que afirma que: "a relação com o Outro é a base de uma co-presença ética". Cada um é constantemente confrontado com um próximo. O autor também afirma que a proposta da alteridade rompe com a perspectiva autonomista individual para remetê-la a uma visão de rede social. Deixa de ter sentido a máxima "A minha liberdade termina quando começa a dos outros", sendo substituída pela proposta de que a minha liberdade é garantida pela liberdade dos outros. Preceitos de alteridade apoiam-se na concepção de que todo o homem social interage e interdepende de outros indivíduos. Assim, como muitos antropólogos e cientistas sociais a existência do "eu-individual" só é permitida mediante um contato com o outro que, em uma visão expandida, se torna o Outro. Dessa forma eu apenas existo a partir do outro, da visão do outro, o que me permite também compreender o mundo a partir de um olhar diferenciado, partindo tanto do diferente quanto de mim mesmo, sensibilizado que estou pela experiência do contato. 
Como estas questões de ética e de alteridade podem ser relevantes na formação de professores, mais especificamente no momento dos estágios supervisionados? Pensemos, por exemplo, no ato de receber um convidado para passar algumas semanas em nossa casa. Na sociedade, é de senso comum que um convidado que venha a conviver em sua casa procure compreender e a sistemática de sua família, seus hábitos, suas crenças, suas rotinas e que busque não interferir drasticamente ou causar transtornos. Da mesma forma, na sistemática tradicional dos estágios supervisionados, o estagiário muitas vezes é visto como um mero convidado no ambiente escolar, cabendo a ele adaptar-se a rotina e seguir regras estabelecidas. Talvez esta sistemática tradicional seja o ponto inicial dos problemas éticos e de alteridade que se tornam mais visíveis nas práticas discursivas dos estagiários durante a criação dos relatórios de estágio.

Quando instruídos a escrever suas impressões de forma a sistematizar seu próprio entendimento daquilo que foi vivenciado, os estagiários muitas vezes se mostram despreparados para uma prática discursiva ética e com preceitos de alteridade. Por que? Provavelmente porque muitos se sentem apenas convidados, não tem sensação de pertencimento ao ambiente escolar, não podem guiar suas ações conforme seus próprios pensamentos e também porque, mesmo que queiram, não sabem como fazê-lo pois sua formação inicial não contempla tais aspectos.

Entra então o papel dos formadores que devem assumir a responsabilidade de inserção de tais aspectos na formação inicial e rever as possibilidades do desenvolvimento do estágio nos ambientes escolares conjuntamente com as escolas. As questões a serem levantadas e discutidas seriam: Como transformar a sistemática tradicional dos estágios supervisionados em experiências didáticas significativas para todos os participantes do processo (formadores, professores regentes, estagiários e até mesmo alunos)? Que transformações estas mudanças trariam na prática discursiva dos estagiários?

\section{Fundamentação teórica-metodológica para a análise do relatório - ACD}

A análise crítica do discurso (ACD) é uma abordagem interdisciplinária ao estudo dos textos, que considera a "linguagem como uma forma de prática social" (Fairclough 1989: 20) e pretende “desvelar os fundamentos ideológicos do discurso que 
se têm feito tão naturais ao longo do tempo que começamos a tratá-los como comuns, aceitáveis e traços naturais do discurso” (Teo 2000).

Pedroza (sem data) apresenta uma retrospectiva histórica da ACD e aponta conceitos básicos para esta metodologia de análise: o discurso, o contexto, o sujeito, a identidade, a intertextualidade ou interdiscursividade, a crítica, a ideologia e o poder remetendo-se as idéias propostas por Fairclough (2001), Meyer (2003) e Wodak (2003). Fairclough (2001) defende o discurso como prática política e ideológica. Como prática política, o discurso estabelece, mantém e transforma as relações de poder e as entidades coletivas em que existem tais relações. Como prática ideológica, o discurso constitui, naturaliza, mantém e também transforma os significados de mundo nas mais diversas posições das relações de poder.

Para a ACD, o contexto explicitamente inclui elementos sociopsicológicos, políticos e ideológicos e, portanto, postula um procedimento interdisciplinar (MEYER, 2003: 37). Os discursos são históricos e só podem ser entendidos se em referência a seus contextos (FAIRCLOUGH, 2003).

Para Fairclough (2001), os sujeitos podem contrapor e, de forma progressiva, reestruturar a dominação e as formações mediante a prática, isto é, os sujeitos sociais são moldados pelas práticas discursivas, mas também são capazes de remodelar e reestruturar essas práticas. Na ACD, rejeita-se firmemente a noção de 'sujeito assujeitado’.

Na ACD, a identidade tem a ver com a origem social, gênero, classe, atitudes, crenças de um falante, e é expressa a partir das formas lingüísticas e dos significados que esse falante seleciona, passando-se à maneira como o produtor de um texto (editor) retextualiza a fala de um locutor, atribuindo-se uma identidade e outra para esse locutor. Da mesma forma, as categorias intertextualidade e a interdiscursividade são bastante exploradas pela ACD, pois elas analisam as relações de um texto ou um discurso, considerando outros que lhe são recorrentes.

Para a ACD, a crítica é concebida como o resultado de certa distância dos dados, considerados na perspectiva social e mediante uma atitude política e centrada na autocrítica. Já ideologia é um termo utilizado para indicar o estabelecimento e conservação de relações desiguais de poder. Ele "se refere às formas e aos processos sociais em cujo seio, e por cujo meio, circulam as formas simbólicas no mundo social” 
(WODAK, 2003: 30). Por isso, a ACD indica, como um de seus objetivos, a desmitificação dos discursos por meio da decifração da ideologia.

A ideologia, segundo Karl Marx, pode ser considerada um instrumento de dominação que age através do convencimento (e não da força), de forma prescritiva, alienando a consciência humana e mascarando a realidade. Ele desenvolveu uma teoria a respeito da ideologia, na qual concebe a mesma como uma consciência falsa, proveniente da divisão do trabalho manual e intelectual. Nessa divisão, surgem os ideólogos ou intelectuais que passam através de idéias impostas a dominar através das relações de produção e das classes que esses criam na sociedade. Contudo a ideologia (falsa consciência) gera, inverte ou camufla a realidade, para os ideais ou vontades da classe dominante. (Marx e Engels, 2002)

A linguagem classifica o poder e expressa poder. Esse poder se manifesta segundo os usos que as pessoas fazem da linguagem e suas competências para tanto. Ele pode ser, em alguns casos, negociado ou mesmo disputado, pois é rara a ocasião em que um texto é obra de uma pessoa só.

Pedrosa (sem data) também demonstra o modelo tridimensional de análise de Fairclough que apresenta três dimensões: a análise textual (que cuida da análise lingüística), a análise discursiva (leva em conta a prática social como algo que as pessoas, ativamente, produzem e apreendem com embasamento em procedimentos compartidos consensualmente) e a análise social (que objetiva analisar os efeitos da prática discursiva sobre a prática social). É a partir deste modelo que um trecho de um relatório de uma estagiária será analisado a seguir.

\section{O discurso produzido e analisado a partir do modelo tridimensional de Fairclough}

Vinte relatórios de observação foram entregues pelas discentes ao término do Estágio Supervisionado de Língua Inglesa 2 no segundo semestre de 2007. Faremos um estudo de caso, nos concentrando em um trecho de um destes relatórios.

A escolha deste relatório (dentre os 20) foi feita porque a autora deste artigo/professora formadora acredita que ele, em termos gerais, é um modelo representativo dos relatórios que têm sido entregues até então. A escolha do trecho se deve à ênfase que foi dada à descrição das aulas e à atuação do/a professor/a regente. 
"Com relação à observação das aulas posso dizer que foram muito positivas, no sentido de que pude perceber quais os métodos essenciais para o desenvolvimento da aprendizagem, organização e interação efetiva do aluno, além de refletir muito sobre várias atitudes que foram tomadas em sala, que na minha opinião foram infelizes, e de que forma alguma usarei destas como futura administradora do conhecimento.

A "professora" regente observada não é uma pessoa dinâmica, determinada e interessada, a sua metodologia se restringe ao livro e quadro, fala muitas palavras em inglês na sala e não as traduz para os alunos, e também não trabalha a interação da língua entre eles, simplesmente dá aquela aula simples, insuficiente e pronto, como se fosse uma obrigação, suas aulas são extremamente maçantes, repetitivas, não as prepara nem as cronometra com antecedência, devido a sua demora para organizar a sala, a aula sempre acaba durante a explicação, prejudicando assim o processo de interação professor-aluno dentro da sala, requisito essencial para o desenvolvimento do aprendizado, ela deixa a tarefa anotada no quadro e saí, os alunos sempre a trazem sem fazer, e não pela dificuldade em traduzir os enunciados, ou pela linguagem do livro como ela afirmou quando a questionei sobre o material didático, mas sim por falta de compreensão da explicação, os alunos se queixam de que toda aula é a mesma coisa, sempre pedem filmes e música para a professora, comentam que as outras salas fazem atividades extra-classe e que gostariam de ter aulas mais descontraídas.

Até ter a oportunidade de assistir a aula de um "professor" regente de outra disciplina, sinceramente imaginei que os alunos é que eram indisciplinados, pois antes de entrarmos nas salas a professora sempre fazia algum comentário negativo sobre a turma. Pode-se dizer que a didática usada em sala de aula por esta professora gera uma reação negativa na aprendizagem, sabemos que as aulas maçantes, repetitivas não são capazes de proporcionar uma aprendizagem significativa para o aluno, comprovando assim a deficiência na relação ensino-aprendizagem, professor-aluno $e$ prejudicando os objetivos do ensino

Esta foi uma experiência única, as aulas observadas, analisadas como um todo se completaram, formando algumas dúvidas, fáceis de se solucionar, mas com um mesmo objetivo e ponto de vista, portanto não venho através deste fazer uma crítica destrutiva ao trabalho da professora regente observada, mas sim expor acontecimentos e situações do contexto escolar, para a partir deles não só desenvolver um perfil único de lecionar, mas também, poder ser um objeto de exploração de professores, para poder contribuir no desenvolvimento de uma nova técnica ou didática, criando situações para desenvolver a eficiência no ensino, dando dicas, como fiz e tenho feito com os professores que observei, e que venho mantendo contato.

Na minha opinião, um dos requisitos que ajudaria a desenvolver o interesse dos alunos pela aula, é conciliá-la a realidade e ao interesse de cada um, dar oportunidades para que possam expor os assuntos que os interessam, claro que dentro de uma disciplina, e a partir daí expor desafios, instigar, motivá-los, criar situações em que pudessem debater tais assuntos, dentro do contexto da matéria.

O estágio de observação foi uma ferramenta, ou seja, o fechamento essencial de fim do ano para o meu desenvolvimento discente. Jamais teria condições de assumir uma sala de aula sem viver esta experiência, antes tinha uma visão completamente diferente das nossas escolas e professores, tive a oportunidade de observar duas formas muito diferentes de lecionar, e com isso pude refletir, sobre muitas formas de se dar 
aula, e que a melhor forma sempre, é fazer de um jeito que me dê prazer em fazer, pois o resultado virá com a conseqüência de um bom trabalho.

\section{Análise social}

Iniciamos com uma análise social do discurso tentando entender a prática social na qual este discurso está inserido para explicar porque ela se apresenta da forma como se apresenta. No que se refere à matriz social do discurso, a estruturação das propostas do ES em questão é de responsabilidade dos professores formadores, mais especificamente aqueles que trabalham com os estagiários de Língua Portuguesa e Língua Inglesa. Não houve, até então, diálogo com os docentes de outras disciplinas do curso de Letras que, entende-se, também são responsáveis por esta formação.

Os estagiários, por sua vez, recebem a proposta pronta com detalhes do que deve ser feito e de como deve ser feito. Sobre as representações expressas pela estagiária no trecho acima, podemos dizer que são representações expressas em uma fase inicial do processo de formação. Espera-se que as experiências de regência e as leituras que ainda estão por vir venham ‘abalar’ as crenças e as percepções dos discentes.

Quanto aos efeitos ideológicos e políticos do discurso, o texto da estagiária reproduz idéias já propagadas por outras instâncias socializadoras (mídia, sociedade e até mesmo pela própria escola). Ao focar na imagem do professor desmotivado e despreparado e inferindo a existência de um ensino deficitário.

\section{Análise discursiva}

Começaremos considerando a interdiscursividade e a intertextualidade ao compreendermos que, em geral, os textos são repletos de fragmentos de outros textos, como se fossem 'respostas' a textos anteriores. Em outras palavras, nosso discurso é constituído pelos discursos de outros.

A intertextualidade no trecho do relatório não é manifesta (não recorre explicitamente a outros textos específicos), mas sim uma intertextualidade constitutiva ou interdiscursividade. O discurso produzido parece remeter ao discurso presentes em livros de didática e também a elementos do discurso cotidiano (produzido pelos membros da sociedade sobre a situação da educação no Brasil).

No ano de 2008, os estagiários (inclusive a informante) fizeram a disciplina de didática e esta experiência parece ter influenciado na escrita do relatório. Podemos ver 
isto em trechos como: "Pode-se dizer que a didática usada em sala de aula por esta professora gera uma reação negativa na aprendizagem" ou no trecho que postula sobre métodos de ensino "pude perceber quais os métodos essenciais para o desenvolvimento da aprendizagem” ou quando se refere à prática pedagógica da professora e comenta: "prejudicando assim o processo de interação professor-aluno dentro da sala, requisito essencial para o desenvolvimento do aprendizado”.

Entretanto, há um momento em que a estagiária se remete ao discurso de outros para dar credibilidade ao seu próprio discurso. Vejamos o trecho: “os alunos se queixam de que toda aula é a mesma coisa, sempre pedem filmes e música para a professora, comentam que as outras salas fazem atividades extra-classe e que gostariam de ter aulas mais descontraídas.” Neste caso, a estagiária “dá voz aos aluno” para expressar sua própria opinião de que as aulas de inglês devem ser ministradas com o auxílio de recursos que extrapolem o material didático.

No trecho: "simplesmente dá aquela aula simples, insuficiente e pronto, como se fosse uma obrigação" ou no " suas aulas são extremamente maçantes, repetitivas”, a estagiária parece reproduzir o senso comum, a idéia que a sociedade tem de um ensino público deficitário resultante da incapacidade do professorado. Estas afirmações desconsideram as imposições que o contexto escolar exerce sobre o trabalho docente.

Ao produzir o texto, a informante cria proposições como forma de manipular os leitores a conceber a professora regente como uma profissional que não cumpre suas tarefas. É difícil não sucumbir a esta idéia ao nos depararmos com os seguintes trechos: "várias atitudes que foram tomadas em sala, que na minha opinião foram infelizes"; “ela deixa a tarefa anotada no quadro e saí” e "Pode-se dizer que a didática usada em sala de aula por esta professora gera uma reação negativa na aprendizagem”

As frases negativas são utilizadas com objetivos polêmicos veiculando pressuposições para depois contradizê-las e rejeita-las. No trecho "A 'professora' regente observada não é uma pessoa dinâmica, determinada e interessada” a informante usa a negativa exatamente para apontar quais as qualidades que ela julga necessárias para o professor. Da mesma forma, quando escreve "fala muitas palavras em inglês na sala e não as traduz para os alunos, e também não trabalha a interação da língua entre eles" a informante continua utilizando a negativa para expor o que seria o ideal em seu ponto de vista. 
Sobre as condições da prática discursiva, é importante lembrar que os estagiários, ao produzirem os relatórios, têm em mente que os professores formadores (supervisores de ES) são os interlocutores, os consumidores deste discurso. No trecho em análise, a estagiária se utiliza da linguagem para apresentar suas percepções sabendo que o ‘consumo' do texto será feito por um leitor apenas, o professor formador.

Mas é importante ressaltar que o consumo do texto é marcado pela busca de coerência tanto para aquele que escreve quanto para aquele que o interpreta. O texto é produzido de forma a expressar as representações da estagiária a respeito:

1) do processo de observação das aulas que a estagiária considera "muito positivas” ou "fechamento essencial” ou “uma experiência única” e até mesmo "uma ferramenta";

2) das características pessoais da professora regente quando relata "não é dinâmica, determinada e interessada";

3) da prática pedagógica da professora quando relata "a didática usada em sala de aula por esta professora gera uma reação negativa na aprendizagem" ou no trecho "várias atitudes tomadas em sala de aula, que na minha opinião foram infelizes”;

4) do entendimento da estagiária do que seria uma prática pedagógica eficaz como no trecho "um dos requisitos que ajudaria a desenvolver o interesse dos alunos pela aula, é concilia-la a realidade e ao interesse dos aluno";

5) o entendimento de como se chegar a esta prática eficaz quando afirma que " $a$ melhor forma sempre, é fazer de um jeito que dê prazer em fazer, pois o resultado virá com a conseqüência de um bom trabalho" ou no trecho que relata como fazer: "expor desafios, instigar, motivá-los, criar situações em que pudessem debater tais assuntos, dentro do contexto da matéria” ou no trecho em que afirma que as dúvidas que surgiram durante a observações das aulas são “fáceis de solucionar";

6) das potencialidades de consumo dos relatos constantes no próprio relatório produzido por ela, ao afirmar estes relatos são exposições de "acontecimentos e situações do contexto escolar para, a partir deles, não só desenvolver um perfil único de lecionar, mas também poder ser um objeto de exploração de professores, para poder contribuir no desenvolvimento de uma nova técnica ou didática”, a estagiária continua ressaltando as potencialidades dos relatos produzidos por ela ao afirmar que estes criam "situações para desenvolver a eficiência no ensino, dando dicas, como fiz e tenho feito com os professores que observei, e que venho mantendo contato." 
A incoerência fica expressa quando consideramos os enfoques dados acima e nos deparamos com o trecho do relatório que diz: "portanto não venho através deste fazer uma crítica destrutiva ao trabalho da professora regente observada, mas sim expor acontecimentos e situações do contexto escolar”. Não vem fazer uma crítica destrutiva, será?

\section{Análise textual}

Quanto ao vocabulário ou as lexicalizações adotadas pela estagiária, podemos destacar o uso metafórico da palavra “ferramenta” para designar o processo de estágio. Ora, o termo ferramenta nos remete a idéia de utensílios utilizados por um trabalhador para desempenhar uma determinada tarefa. Sem a ferramenta, o profissional fica parcialmente ou totalmente impossibilitado de cumprir suas funções. É desta forma que a estagiária vê o papel do ES2, como essencial, o que se comprova quando afirma que “Jamais teria condições de assumir uma sala de aula sem viver esta experiência”.

No que se refere à gramática, podemos considerar que modelos e estruturas das orações demonstram o significado e a construção de identidades sociais de relações sociais de crenças e conhecimentos (Pedroza, sem data). O texto em questão é repleto de orações declarativas cujos verbos se apresentam no tempo presente, o que dá um ar de autoritarismo. Além disto, todas as frases do trecho analisado estão na voz ativa impossibilitando, desta forma, a omissão do agente.

Quanto à modalização do discurso (o fenômeno que se caracteriza pelo aparecimento de um advérbio ou locução adverbial que qualifica não só uma palavra, mas também um predicado inteiro, expressando o relacionamento do sujeito com a sua proposição), é possível notar a utilização de recursos modalizadores nos trechos em que a estagiária se refere à observação das aulas e as qualifica como " $\underline{\text { muito }}$ positivas” ou quando remete-se a prática do professor, quando afirma: “simplemente dá aula”, ou quando retoma suas próprias percepções sobre os alunos:”sinceramente imaginei que os alunos é que eram indisciplinados" e quando fala sobre a escola: "antes tinha uma visão completamente diferente das nossas escola e professores”. Os agentes modalizadores são utilizados para dar ênfase a idéia que a autora do texto quer propagar. 
A identidade social da estagiária se dá na construção deste discurso. O seu discurso demonstra a posição social que ocupa, ou que pensa ocupar. As marcas são de identificação com os alunos, ao invés da identificação com a professora observada. O papel é realmente daquela que observa, confortavelmente instalada em uma instância sociedade que olha a escola com olhar de desconfiança. O trecho demonstra que a estagiária, mesmo não sendo e não se colocando como pertencente à escola, se põe na posição daquela que pode contribuir com o processo e fazer melhor do que está sendo feito. Ela até mesmo antevê seu papel de “futura administradora do conhecimento."

\section{Retomando os questionamentos iniciais diante da análise realizada}

Diante do contexto específico da análise feita até aqui, podemos concluir que os estagiários não foram instruídos (ou se foram, não souberam considerar estas instruções) sobre a linguagem a ser utilizada para se falar sobre as aulas e sobre os/as professores/as regentes. Como professora formadora, me lembro de ter comentado brevemente sobre a linguagem a ser utilizada. Minhas instruções foram que mesmo que o estágio não previsse que a professora regente teria acesso ao relatório, este deveria ser produzido de tal forma a não denegrir a imagem deste profissional e que, caso o relatório chegasse às mãos do professor, este não se sentiria ‘agredido’ ou humilhado. Na prática, o ‘faz de conta' da possibilidade do professor regente ter acesso ao relatório não surtiu efeito, exatamente porque ao produzir o discurso a estagiária sabia que o seu interlocutor era apenas a professora formadora, nem mesmo era previsto que as outras estagiárias tivessem acesso ao relatório. Lição: preceitos de ética e alteridade não são apreendidos através de suposições, é preciso criar novas sistemáticas para que o estagiário realmente ‘calce o sapato’ do professor e descreva suas impressões não como aquele que está de fora, mas como aquele que está em busca de pertencer ao ambiente escolar.

Quanto às relações que formadores e discentes tem buscado estabelecer entre princípios éticos e práticas discursivas, focando no contexto analisado, creio que estas questões ainda estão pendentes. Em anos anteriores, os estagiários sempre questionavam o processo de produção de diários das aulas observadas; queriam saber exatamente o que, quanto e como deviam escrever. Na busca de sanar estes questionamentos e já tendo em mente que os diários produzidos pelos discentes até 
então costumavam focar apenas na prática do professor e no comportamento dos alunos, os professores formadores e discentes do $3^{\circ}$. Ano de Letras produziram de forma conjunta um roteiro para a confecção dos diários (anexo 1). O roteiro foca no contexto educacional, na prática docente, na aprendizagem e nos materiais/recursos didáticos. Creio que esta foi uma primeira tentativa de intervenção no processo da escrita dos alunos com potencial para inserir as questões éticas. Entretanto, o trecho do relatório em questão foi produzido após a construção coletiva deste roteiro, o que aparentemente compromete o alcance dos resultados esperados.

A estruturação do estágio de observação, no contexto analisado, se mostra como um dos principais fatores para a não consideração de preceitos éticos e de alteridade. $O$ período de observação é curto, apenas 15 horas/aula, nas quais os estagiários acompanham professores em várias turmas. É um processo conhecido como 'dar sem receber’. O professor dá ao estagiário a oportunidade de entrar em seu ambiente de trabalho, a oportunidade de vivenciar o seu dia a dia. E o estagiário (leia-se instituição superior de ensino), o que oferece ao professor? Além disto, o produto que resulta deste processo, o relatório, ainda é cercado de julgamento de valores e representações precoces. É também importante ressaltar que os relatórios não prevêem o anonimato dos professores, pelo contrário (vide anexo 3), prevêem uma descrição elaborada do perfil do professor.

\section{E agora, José?}

A introdução de preceitos de ética e de alteridade deve passar a ser assunto de pauta nos cursos de formação inicial, principalmente no que tange a prática discursiva do estagiário. Mas quais seriam as sistemáticas para introdução/re-alimentação destes preceitos na formação inicial? Seguem algumas considerações:

- Faz-se necessária a inserção de textos teóricos sobre o tema em disciplinas de lingüística aplicada para que discussões sejam levantadas e as representações dos discentes sejam consideradas;

- Os momentos de orientação entre formadores e estagiários podem e devem ser oportunidades de considerar preceitos de ética e de alteridade. Melhor ainda seria que os professores regentes também pudessem fazer parte deste momento; 
- A estruturação do estágio é uma questão que deve estar sempre em pauta e, se possível, contar com a participação de todos os envolvidos: os formadores, os professores regentes e os próprios estagiários.

- Faz-se necessário considerar a inserção do professor regente como um participante ativo dentro do processo de estágio (é bom lembrar que sem sua permissão o estágio simplesmente não acontece) uma vez que um trabalho conjunto entre participantes já traz consigo o potencial de ser um trabalho com preceitos de ética e alteridade. Entretanto, a formação inicial de um profissional é uma incumbência trabalhosa. Estão os professores regentes dispostos a fazer parte desta formação assumindo parte destas incumbências?

- Para as produções escritas já feitas sem a devida consideração a preceitos éticos, existe a possibilidade de propor um re-escritura de diários e relatórios buscando adequação a estes preceitos.

No que tange à prática discursiva, Gutíerrez e Rogoff (2004), ao analisar as generalizações em pesquisas produzidas considerando diferentes ambientes culturais de indivíduos, apontam que é aconselhável falar sobre suas impressões ou descobertas usando os verbos no passado ao invés do presente. O uso do passado marca impressões ou descobertas do que foi observado ao invés de assumir uma verdade sem tempo determinado.

Concluindo, é importante salientar que a experiência da alteridade parece não estar sendo vivenciada nas atividades propostas pelo ES e esta situação acaba se refletindo nas práticas discursivas dos participantes, o que, por sua vez, compromete o relacionamento ético.

Por fim, se o processo de formação não for capaz de promover estas mudanças de percepções e aprimorar a produção discursiva em seus preceitos de ética e alteridade, a Universidade será (ou continuará sendo vista) apenas como instância reflexa da sociedade e do mundo do trabalho, como alertam as Diretrizes Curriculares. Se o que buscamos é a universidade como ser um espaço de cultura e de imaginação criativa, capaz de intervir na sociedade, transformando-a em termos éticos, então as práticas discursivas devem ser revistas, exploradas e aprimoradas. 


\section{Referências bibliográficas}

CELANI, A. Questões de ética na pesquisa em Lingüística Aplicada. In: Linguagem \& Ensino, Vol 8, N.1, 2005 (101-122)

FAIRCLOUGH, N. Discurso e mudança social. Brasília: Universidade de Brasília, 2001.

FREIRE, M.M.; LESSA, A.B.C. Professores de inglês da rede pública: suas representações, seus repertórios e nossas interpretações. In: BARBARA, L.; RAMOS, R. (Org.) Reflexão e ações no ensino-aprendizagem de línguas. Campinas: Mercado de Letras, 2003. p.167-194.

GOLDIM. As idéias filosóficas contemporâneas na França. São Paulo: Jorge Zahar, 1991:85. Disponível em http://www.ufrgs.br/bioetica/alterid.htm. Acessado em 28/07/2008

GUTÍERREZ \& ROGOFF. Cultural ways of learning: Individual traits or repertories of practice. In: Educartional Research. Vol 32, Number 5, 2004

MARX, K. e ENGELS, F.. A Ideologia Alemã (Feuerbach). São Paulo: Hucitec, 2002.

MEYER, M.. Entre la teoría, el método y la política: la ubicación de los enfoques relacionados con el ACD. In: WODAK, Ruth; MEYER, Michel. Métodos de análisis crítico del discurso. Barcelona: Gedisa, 2003, p. 35-59.

PEDROSA. Análise crítica do discurso: uma proposta para a análise crítica da linguagem. Disponível em http://www.filologia.org.br/ixcnlf/3/04.htm. Acessado em 28/07/2008

TEO, PETER. 2000. Racism in the news: a Critical Discourse Analysis of news reporting in two Australian newspapers. Discourse and Society, 11: 1, 7-49. [Cited in Talbot, Atkinson and Atkinson 2003: 36.]

WODAK, R. De qué trata el análisis crítico del discurso. Resumen de su historia, sus conceptos fundamentales y sus desarrollos. In: —; MEYER, Michel (orgs.). Métodos de Análisis Crítico del Discurso. Barcelona: Gedisa, 2003, p. 17-34. 


\section{ANEXO 1}

\section{Contexto Educacional:}

A. Descreva o espaço físico da escola (ex. a secretaria, a diretoria, a biblioteca, os laboratórios, a sala dos professores, a cantina) e comente sobre como a distribuição e aproveitamento desse espaço facilitam/inibem o trabalho dos professores e da aprendizagem dos alunos

B. Comente sobre a interação direção/ coordenação/ professores/ comunidade

C. Comente sobre o status da LI para alunos, professores, supervisores e diretores.

D. Comente sobre os procedimentos burocráticos da escola (ex. preenchimento de pautas regularidade das reuniões pedagógicas).

E. Descreva o contexto sócio-histórico dos alunos e dos professores

F. Comente sobre as normas e regras da escola e como estas são vinculadas

G. Comente sobre os eventos realizados na escola e sua relação com a disciplina de LI

H. Comente sobre a receptividade de alunos, professores, supervisores e diretores com os estagiários

\section{Prática Docente:}

A. Comente sobre os papéis que o professor desempenha em suas aulas e como esses papéis favorecem/inibem o aprendizado dos alunos. Dê suporte aos seus comentários

B. Comente sobre os padrões de interação estabelecidos pelo professor em sala de aula

C. Comente sobre possíveis enfoques em alguma habilidade específica (reading, writing, listening, speaking)

D. Comente sobre o material didático, sua utilização e sua adequação às características/necessidades dos alunos

E. Aponte o papel da gramática nas aulas de LI 
F. Descreva a rotina do professor (quantas aulas por semana, quantas escolas, quantas turmas, quantos alunos).

G. Descreva o processo de avaliação da aprendizagem dos alunos.

H. Comente sobre a proficiência lingüística do professor e como esta contribui (ou não) para ao aprendizado

I. Comente sobre a formação continuada do professor

\section{Aprendizagem:}

A. Comente sobre a participação dos alunos em sala (ex: fazem perguntas, colaboram com seus conhecimentos, mostram-se interessados). Destaque evidências

B. Comente sobre os papéis que os alunos desempenham nas aulas e de que maneira você acha que esses papéis favorecem/inibem seu o aprendizado. Dê suporte aos seus comentários

C. Comente as maneiras pelas quais alunos e professor interagem (ex. espontaneamente, unilateralmente, respeitosamente, atentamente) e sobre quão próxima/distante essa interação está daquilo que você considera ideal para a experiência escolar bem sucedida

D. Faça relações entre o material didático, a prática do professor e a aprendizagem dos alunos

E. Comente sobre como o processo de avaliação adotado pelo professor contribui ou não para a aprendizagem dos alunos

F. Comente sobre fatores motivacionais

\section{Material Didático/ Recursos didáticos}

A. Relate os recursos didáticos utilizados pelo professor e como estes influenciam no processo de ensino/ aprendizagem

B. Comente sobre possíveis recursos didáticos que estejam sendo pouco/ou não explorados. Comente sobre como novos recursos poderiam contribuir para o processo de ensino/aprendizagem.

Em caso de utilização de livro didático 
A. Comente sobre o papel do livro didático nas aulas (ponto de apoio, fonte única, etc).

B. Comente sobre os materiais utilizados e de que forma estes promovem o desenvolvimento da criticidade do aluno.

C. Analise o livro didático refletindo sobre sua atualização, conteúdo, linguagem, qualidade e estrutura

ANEXO 2

Prática de Ensino/Estágio Supervisionado de Língua Portuguesa/ Inglesa II (40h/a cada) ENSINO FUNDAMENTAL E MÉDIO

PROPOSTA METODOLÓGICA:

DRAMATIZAÇÃO NO CONTEXTO ESCOLAR

- $\quad$ 15h/a - Observação nos Ensino Fundamental e Médio

O estagiário atua juntamente com o professor regente - 10 h/a no Ensino Fundamental e 5 h/a no Ensino Médio - em trabalhos como: estudos dirigidos, orientação de grupos de estudo, aplicação de testes, realização de exercícios, e outras atividades autorizadas pelo professor regente. Após cada observação, devem ser produzidos diários das aulas conforme guia de observação no anexo 9.3.

- 05 h/a - Preparação de relatório crítico do estágio nos Ensinos Fundamental e Médio (individual ou em dupla)

Após realização das 15h/a de observação, os estagiários devem confeccionar um relatório crítico de observação conforme anexo 10.2. O relatório deve ser entregue até 3 semanas após o término do período de observação.

- 10 h/a - Estudos teóricos (Documentos governamentais)

Os estagiários realizam grupos de estudos sobre documentos governamentais (como, por exemplo, PCN e Diretrizes Curriculares), em horário estabelecido pela professora supervisora 
de estágio, a fim de discutir os textos institucionais e suas diversidades em relação ao ensino/aprendizagem da língua portuguesa / inglesa. Troca de experiências através de exposição oral.

- 10 h/a - Dramatização

Os estagiários estudam os diários produzidos nas observações de estágio e elaboram texto teatral sobre o contexto de ensino da língua portuguesa / inglesa, conforme estabelecido em reunião presencial com a professora supervisora de estágio, a fim de encená-lo em dia e horário a combinar.

ANEXO 3

\section{ESTÁGIO SUPERVISIONADO II / DRAMATIZAÇÃO / Estrutura do Relatório}

\section{Sumário}

Introdução (apontando o que será apresentado neste relatório)

\section{Contexto escolar}

1.1 Local do Estágio (Nome do colégio, endereço completo)

1.2 Informações sobre o Professor regente

1.3 Série/ Turma em que vai estagiar

1.4 Horário das Aulas

1.5 Material Didático utilizado

1.6 Recursos audiovisuais disponíveis na escola

1.7 Planejamento Anual adotado pelo professor regente

1.8 Métodos de Avaliação adotados pelo professor regente

\section{Diários de observação}

- Levantamento e análise de aspectos mais relevantes (extraído dos diários) 


\section{Dramatização}

- Descrição do cenário

- Composição dos Personagens

- Roteiro da dramatização

\section{ANEXO}

- Ficha de freqüência do período de observação

- $\quad$ Diários de observação 1,2,3,4,5,6,7,8,9,10,11,12,13,14 e 15 